\title{
A Crisis of the European Model? Reflections and Projections
}

\author{
Iordan Gheorghe B $\breve{A R B U L E S C U}$ \\ Andra-Maria POPA
}

\begin{abstract}
The multiple crises of the first two decades of the $21^{\text {st }}$ century had a great impact on the European Union. As a result, a thorough reflection on the design of the European model is required and a reassessment of its goals is needed. This paper argues that differentiated integration describes best the current model of European integration and that it is favourable for creating, on long-term, a more united Europe. After briefly explaining what the 'European model' stands for, the paper analyses the impact of the crises on the European economic governance framework - as the most decisively challenged dimension of the model - and presents some scenarios for the immediate future development of the European model of integration.
\end{abstract}

Keywords: the European model, differentiated integration, spill-over effects, the EU crisis, European economic governance

\section{Introduction}

The talk about the European model in the context of the crisis which has affected the European Union (EU) for the last 5 years is a debate about the future of the European Union (EU). Would this future mean 'more Europe', having competences in more policy fields (e.g. fiscal policy) and completing the political union or, on the contrary, would the crisis determine a pressure for returning competences to the national level? Would it be 'more Europe' for all member states or only for some? Both the late-2000s global financial crisis and the accompanying recession have hit Europe very hard and its countries quite differently. But the European sovereign debt crisis (better known as the Eurozone crisis), which started in 2010, has had the greatest impact on the EU as a community of states, putting its unity and solidarity to the supreme test. All these events happened on a background of diminishing trust of the public opinion within the member states both in EU institutions and in the EU project as a whole. ${ }^{1}$ This pushes for yet another reassessment of EU's boundaries and of its development model.

The traditional scholarly work regarding the future of the European integration (EI) process is mainly gathered around the key theories of EI and reflects a biased view emerging from the normative vision of the great EI theories. Thus, the federalists and neofunctionalists see, as an end result of the integration process, a

1 According to the Standard Euro-barometer (EComm 2012a, p. 14 - trust in the EU; EComm 2012 b, pp. 59-63 - trust in EU institutions), the trust of the public in the EU has been declining since Spring 2007, a quite dramatically decrease in trust in the EU happening between Spring 2011 and Autumn 2011, when it dropped from 41\% to 34\%. 
genuine political community of member states and believe the EU would slowly turn into a democratic European federation. The intergovernmentalists and liberal intergovernmentalists, on the other hand, see the EU as a group of strong national states, which cooperate with one another especially on low politics issues and make use of the EU institutional environment only to promote their domestic preferences and interests. Therefore, in their view, the EU is a special case of confederation.

The crisis has shown that there is no either-or answer to the question how would the EU model of integration look like in the future. The authors of this paper argue that differentiated integration describes best the current model of European integration and that it is favourable for creating a more united Europe. The main reason for promoting this argument would be that by creating closer cooperation between some member states on specific policy issues, it would trigger some sort of spill-over effect on other policy areas and this process would attract other member states as well. They believe that differentiated integration has the potential ${ }^{2}$ of slowly, but progressively, turning into unified integration by attracting more member states in the process and widening its policy coverage. Growing on this belief, the authors have chosen to write a conceptual paper on how the European model was affected by the crisis and try to make some assumptions on the direction in which the EU will develop in the near future. Their writing is based on the theoretical background of differentiated integration and the issue of the spill-over effect, which is detailed in the first part of the paper. The second part provides a conceptual delimitation of what the authors understand by the 'European model'. This is followed by a brief review of the impact of the crisis on this model, through analyzing its implications for the European economic governance model. ${ }^{3}$ And last, but not least, the authors state their views of the future development of the European model of integration.

\section{Theoretical background: differentiated integration and the spill-over effect}

Despite the vivid debates on the future of the EU, which take place between federalists and intergovernmentalists, reality has shown that the European project

2 As pointed out by Joschka Fischer in his speech "From Confederacy to Federation Thoughts on the finality of European integration" (2000, May 12, p. 8) at the Humboldt University in Berlin, "closer cooperation does not automatically lead to full integration"; deliberate political action is needed for completing the political union.

3 The authors chose to focus on analysing the impact of the crisis on the economic governance dimension of the European model, because they consider this component to be the most decisively challenged by the multiple crises of the late 2000s. They also acknowledge the fact that the crises have had an impact also on the social and political dimensions of the model, but they believe that the flaws in the economic governance pillar were the main causes which determined a spill-over onto the other two dimensions of the model. 
isn't going in either of the directions pointed out by these theories. It seems that it is rather the concept of differentiated integration which has the ability to encompass the current developments within the EU.

Differentiated integration has preoccupied both the scholarly and the political world for quite a while (ever since the $1970 \mathrm{~s}^{4}$ and especially after the $1990 \mathrm{~s}^{5}$ ), but their interest in this process has increased spectacularly due to the recent events associated with the Eurozone crisis. The literature on this issue is still quite poor, although there exists a plethora of conceptual work; the theoretical framework on the causes and effects of differentiated integration is still underdeveloped and data collection and analysis are nevertheless fuzzy. ${ }^{6}$

Also known as 'flexible integration", the concept of differentiated integration was formally introduced by the Amsterdam Treaty under the name of "closer cooperation' describing the possibility for a group of member states to cooperate more closely in specific policy areas using the institutional framework of the EU. It was then slightly revised and renamed 'enhanced cooperation' by the Treaty of Nice in 2000. As $\mathrm{Stubb}^{8}$ argues, differentiated integration "presents a paradigm shift, because traditional approaches to European integration such as federalism, functionalism, neo-functionalism and intergovernmentalism are all based on the traditional rigid model of integration", namely the unified integration model. Thus, it marks the acknowledgment of the fact that the current European integration process is not based on the 'Monnet method' anymore, but it results in a multitude of subgroups of EU member states which achieve higher levels of integration among themselves. Although Jean Monnet and the other EU founding fathers would have argued that this process is doing nothing but to destroy the integration process

4 The debate on this subject started with the launch of the Tindemans Report in 1975, but continued sporadically until the 1990s.

5 The talks on differentiated integration were revitalized in the 1990s once the German CDU/ CSU parties released in 1994 the study "Reflections on European Policy" (also known as the Lamers \& Schäuble Report).

6 Holzinger, Katharina; Schimmelfennig, Frank, "Differentiated Integration in the European Union: Many Concepts, Sparse Theory, Few Data”, in Journal of European Public Policy, vol.19, no. 2, 2012, pp. 293, 302-303.

7 Alexander C-G. Stubb notes in his paper "The 1996 Intergovernmental Conference and the management of flexible integration" (Journal of European Public Policy, vol. 4, no. 1, 1997, p. 53) that there are three terms used for describing the same process: "differentiated integration [which] is often used in academic literature; flexible integration [...] used in political literature; and enhanced co-operation [...] used in politically correct literature [i.e. in the body of the Treaties]". Within this article, the authors use this terminological differentiation in order for the reader to understand better the object of reference.

8 Stubb, Alexander C-G., Negotiating Flexibility in the European Union, Basingstoke: Palgrave, 2002, p. 165.

9 See also Joschka Fischer's arguments for the replacement of the 'Monnet method' with differentiated integration in his speech given at the Humboldt University in May 2000. 
by fragmenting it, today's policy-makers and political scientists believe that this model allows for more integration, which "would otherwise be blocked by the lack of political will in some member states or by increasing heterogeneity among the members". ${ }^{10}$

In regard to the causes which determine differentiated integration, the most widespread explanations point to the great heterogeneity of the EU member states, as a result of the different enlargement rounds, but also to the design of the EU decision-making system. ${ }^{11}$ In an environment where the states have increasingly different preferences and capabilities, it is very hard to come to an agreement, given the EU institutional framework, where qualified majority and even unanimity are required in decision-making. Thus, the deadlock could be overcome by replacing the big 'integration for all' process with a bunch of smaller, but more profound 'integration for some' processes, between states with similar interests and economic performance.

The most widely accepted and used classification of the types of differentiated integration is provided by Alexander Stubb. ${ }^{12}$ He distinguishes between about 30 modes based on three criteria of differentiation: time, space and matter, and describes accordingly the three main categories of differentiated integration, namely multi-speed ${ }^{13}$, variable geometry ${ }^{14}$ and á la carte. ${ }^{15}$

Holzinger and Schimmelfennig ${ }^{16}$ observe well that Stubb's classification is somehow imprecise and redundant: it is obvious that all types of differentiation imply both a territorial and a sectoral matter, since there are only certain policy areas targeted by differentiated integration and, in every case, there are also states which don't participate in the integration. As an attempt to improve this classification, they suggest a set of six dimensions for assessing the modes of integration ${ }^{17}$ :

10 Holzinger, Schimmelfennig, p. 293.

11 Ibid., p. 299.

12 Stubb, "A Categorization of Differentiated Integration", pp. 283-295.

13 Stubb explains in "A Categorization of Differentiated Integration" (p. 287) that "multispeed' integration is being pursued by a group of member states willing and able to go further with the integration of some policy areas. The other states, which share the same common objectives, would follow later; thus the differentiation is just temporary.

14 Taking into consideration Europe's political, cultural and economic diversity, and therefore the impossibility of pursuing common goals valid for all member states, Stubb (ibid., pp. 287-288) says that this type of integration should allow permanent separation between a core of countries, which pursue deeper integration in some policy areas, and the less developed ones. This type of integration is based on opt-ins.

15 As the name says, member states should be able to choose, like from a menu, in which policy areas they want to go further with the integration, while they still maintain a minimum number of common objectives with all the other states; see Stubb (ibid., p. 288). It is rather based on opt-outs.

16 Holzinger, Schimmelfennig, p. 296.

17 Ibid., p. 297. 
“(1) permanent v. temporary differentiation;

(2) territorial v. purely functional differentiation;

(3) differentiation across nation states v. multi-level differentiation;

(4) differentiation takes place within the EU treaties v. outside the EU treaties;

(5) decision-making at EU level v. at regime level;

(6) only for member states v. also for non-member states/areas outside the EU territory".

Based on these dimensions, they also provide a very comprehensive overview of the distinct types of differentiated integration (see Table 1 below) which can find empirical evidence (all, except the Functional Overlapping Competing Jurisdictions - FOCJ), by giving some examples and indicating the literature on this issue.

An interesting approach on the different modes of differentiated integration within the EU is used by de Neve ${ }^{18}$, who introduces the metaphor of 'European Onion' ${ }^{19}$, which describes the EU as a multi-layered polity where overlapping subgroups of states achieve increasingly higher levels of integration and move slowly towards an 'ever closer Union'. Thus, de $\mathrm{Neve}^{20}$ distinguishes six 'layers' of the EU: the Association Agreements, the Stabilization and Association Agreements, the European Economic Area, the Schengen Agreement, the EU 27 and the Eurozone. The 'layers' are flexible since each state from a marginal layer is allowed to move towards the core, the core of the 'onion' having a centripetal effect on all external layers by pulling the member states to join a more advanced subgroup. ${ }^{21}$ The centripetal effect of the more integrated core combined with a spill-over effect on the connected policy fields would have the potential of attracting all member states to the 'finalité politique'. ${ }^{22}$

18 de Neve, Jan-Emmanuel, "The European Onion? How Differentiated Integration is Reshaping the EU”, in European Integration, vol. 29, no. 4, 2007, pp. 503-521.

19 This model is quite similar to the one called 'Core Europe/Concentric circles' listed by Holzinger and Schimmelfennig in their classification.

20 de Neve, pp. 505-507.

21 Ibid., p. 512.

22 Ibid. 


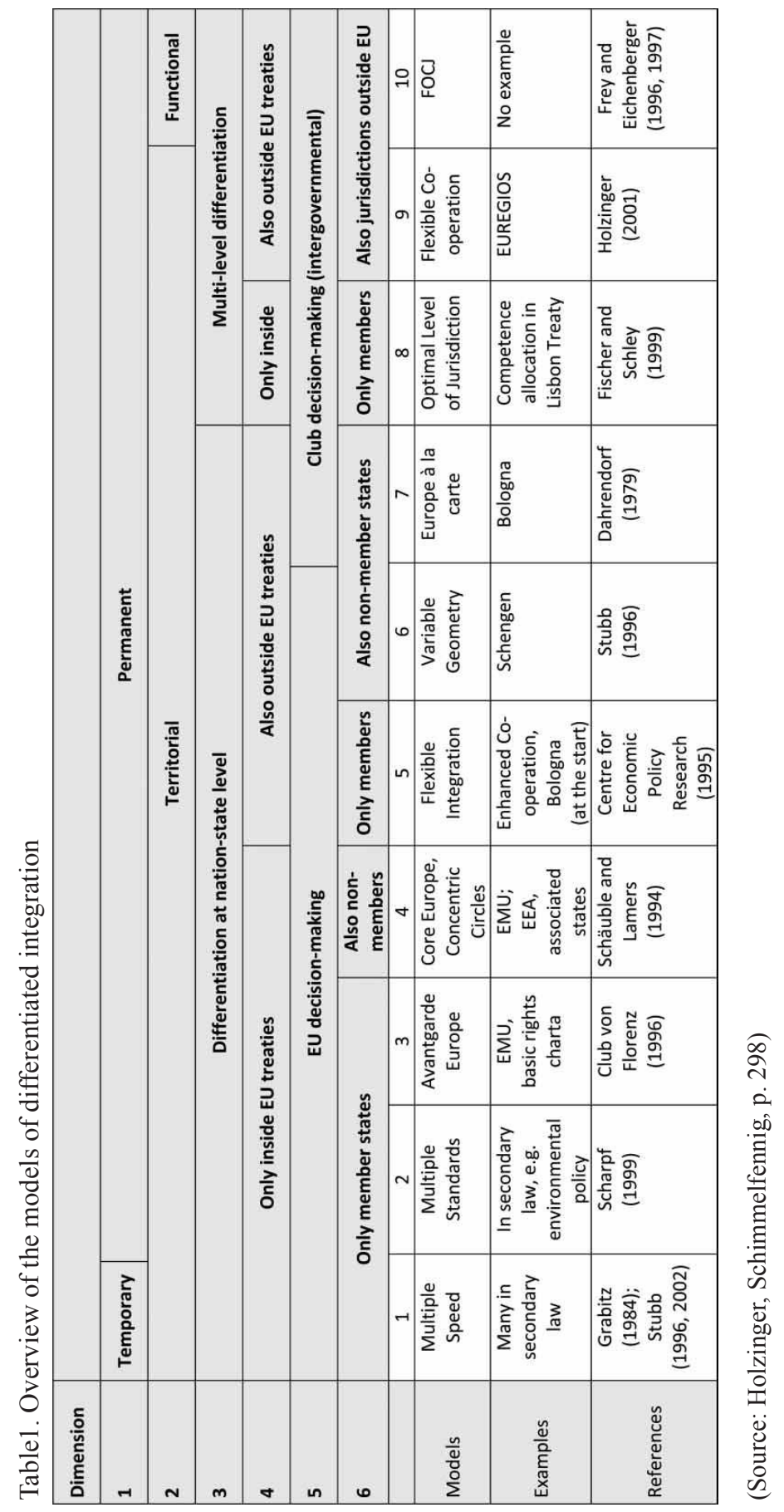


'Spill-over', the key concept of the neofunctionalist theory of European integration, was first defined by Ernst Haas and used for explaining how integrating one economic sector would create pressure for greater integration within that sector and in other economic and political activities, thus giving more authority to the EU level. ${ }^{23}$ Lindberg $^{24}$ describes the process as "a situation in which a given action, related to a specific goal, creates a situation in which the original goal can be assured only by taking further actions, which in turn creates a further condition and a need for more action, and so forth". This means that, once the political cooperation between member states has started in one activity, it has the potential to expand, in time, to other activities which weren't necessary intended in the beginning. As Niemann and Schmitter ${ }^{25}$ argue, some sectors are so interdependent that, when a problem arises on a particular policy issue, it can only be solved by integrating more policy areas.

The early neofunctionalist literature distinguished between two major types of spill-over (i.e. functional ${ }^{26}$ and political ${ }^{27}$ ) and later theorists added two more (i.e. cultivated ${ }^{28}$ and geographical/exogenous $\left.{ }^{29}\right)$.

23 Haas, Ernst B., The Uniting of Europe. Political, social and economic forces 1950 - 1957, Stanford: Stanford University Press, 1958.

24 Lindberg, Leon N., The Political Dynamics of European Economic Integration, Stanford: Stanford University Press, 1963, p. 10.

25 Niemann, Arne; Schmitter, Philippe C., "Neofunctionalism”, in Wiener, Antje; Diez, Thomas (eds.), European Integration Theory, New York: Oxford University Press, 2009, p. 49.

26 'Functional spill-over' refers to the technical pressures, involuntarily generated by the integration of one sector of the member states' economies, which push for a wider integration also in the functionally related sectors. In other words, in order for the integration of one specific policy area to succeed, other, closely interconnected policy areas need to be integrated as well.

27 'Political spill-over' refers to the building-up of political pressure for more integration. This pressure is exert by national elites (governmental or non-governmental), which have come to move part of their activities and expectations to the European level, and based on their previous positive experiences, would now support further integration.

28 'Cultivated spill-over' involves the European Commission's role (or of other European institutions) in making European integration possible by 'cultivating' the national elites (both interest groups and national bureaucrats) in realising the EU objectives.

29 'Geographical spill-over' was the term used by Haas in his work The Uniting of Europe. Political, social and economic forces 1950 - 1957 (pp. 313-317) to explain UK's faltering to join the European Communities in the 1950s. Later on, Niemann and Schmitter (p. 62) in their contribution on neofunctionalism called this effect 'externalization' or 'exogenous spillover'. The cooperation between a group of states is believed to trigger horizontal integration (i.e. enlargement), since the excluded states would feel the pressure of joining the others in order to take advantage of the positive externalities of the integration process and not to experience the negative ones, if they decide to stay outside. Niemann and Schmitter (ibid.) argue that the need for enlargement can be explained by a spill-over effect, which doesn't determine integration of other policy areas, but calls for territorial expansion. 
According to Leuffen et. al. ${ }^{30}$, differentiated integration has two major manifestations: 'vertical differentiation' (European integration differs throughout the policy areas, some policies being more integrated than others) and 'horizontal differentiation' (European integration isn't uniformly applied to all member or nonmember states). In theory, it should be possible for these kinds of differentiations in the European integration process to be smoothened in time, with the help of the integrating pressure delivered through the different types of spill-over mentioned above.

\section{What is the European model?}

Since the paper talks so much about the 'European model', a conceptual delimitation is in order. In this context, the term 'model' can be understood in two ways:

1) "a thing used as an example to follow or imitate" 31 ;

2) (according to the definition in social sciences) a "general sketch of the main features of some social phenomenon" 32 , which tries to abstractly represent and simplify reality by highlighting the relationships between its different aspects.

In line with the first understanding, the European model refers to the model of society the EU wants to develop inside its borders and export to the whole Europe and (maybe) to other regions of the world, as well. While focusing on both deepening and widening ${ }^{33}$, the authors believe the EU seeks to slowly develop into a political organization of federal inspiration and to explicitly extend its model of conflict resolution and generation of wealth throughout most of the states within the European continent and beyond it. The ultimate goal of this 'redefinition' ${ }^{\text {'4 }}$ of Europe is that, through its size, power and unity, it should become a global referential, a model for others, able to contribute to the peaceful management of the current globalized world. In the last 25 years, the model of the EU has quietly turned into a European

30 Leuffen, Dirk; Rittberger, Berthold; Schimmelfennig, Frank, Differentiated Integration: Explaining Variation in the European Union, Basingstoke: Palgrave Macmillan, 2012.

31 http://oxforddictionaries.com/definition/english/model, accessed on 15.02.2013.

32 Bealey, Frank; Johnson, Allan G., The Blackwell dictionary of political science: A User's Guide to Its Terms, Oxford, Massachusetts: Blackwell Publishing Ltd, 1999, p. 214.

33 For more comments on this binomial, see Bărbulescu, Iordan Gh., Uniunea Europeană: Extindere și aprofundare, București: Editura Trei, 2001.

34 When talking about the aim of this 'redefinition' of Europe, it recalls remembering that the EU's founding fathers had in mind, from the beginning, the creation of a federal Europe, open to all European states in search for integration. The on-going process of European integration seems to be moving quietly towards accomplishing their dream, although sometimes the pace is too slow or integration efforts are challenged by current developments in the world and in the EU member states (i.e. the global financial crisis, the recession and the Eurozone crisis) or by manifestations of Euroscepticism within EU leaders; thus the integration process has to adapt its methods to the current challenges (see above, the talk on the need to replace the 'Monnet method' with differentiated integration). 
model. Moreover, in terms of common awareness, Europe has been identified, more and more, with the EU; nowadays, even scientific analyses tend to identify the two entities, mainly due to the EU's high level of institutionalization and its policy area coverage. ${ }^{35}$ These developments took place despite the Euroscepticism emerged in the 1970s, especially in the context of UK's accession, which believed the European Communities would remain just another free trade area. ${ }^{36}$

According to the second definition, the European model can be described as a set of unique characteristics which define the European model of society, mostly in comparison with the Nord-American model, based on the supremacy of markets. Thus, it refers to the specific EU model which promotes a balance between society, economy and politics, and, as Blanchard ${ }^{37}$ says, "combines economic efficiency and generous social insurance". While the Nord-American model includes economic growth and political liberty, but excludes social cohesion, the European model implies all three. The European model is based on a competitive social market economy, while the American one embraces a model of laissez-faire market economy. Economic growth of the American model proved to be more spectacular than in Europe, but not necessarily sustainable. Both value the individual freedom of choice and ownership and use competitive market mechanisms to allocate resources. It should be noted that these differences are presented in terms of the theoretical foundations of the two models, in reality the situation might be different, and the two models might have more things in common than arising from theory. ${ }^{38}$

35 Sawicki, Iwona, "Growing Regionalism in a Shrinking World", in European Policy Centre Working Papers, 2002.

36 This Euroscepticism periodically reappears, as it was in the case of the accession of the Central and Eastern Europe countries (CEECs). Even nowadays there are many scholars who argue that the heterogeneity of the 12 newest EU member states (13 since July 2013), together with the existing development gaps between them and the old members, would make the EU go back to being just a free trade area. The 'failure' in ratifying the Constitutional Treaty in France and the Netherlands in 2005 also contributed to the increase in Euroscepticism. At present, the Eurosceptics strike again and 'preach' the end of the Eurozone and of the EU as a whole, as the extended economic crisis and the sovereign debt crisis of the Eurozone countries only end up supplying these 'apocalyptic' predictions. As permanent Eurosceptic, the UK has once again expressed its thoughts on the future of the European model through the speech of its prime-minister, Mr. David Cameron, which is meant to clearly detach the UK from the group of member states wanting to build 'an ever closer political union', while pleading for a review of EU competences and the possibility of power to flow back to the member states (see Cameron, David, "David Cameron's EU speech in full", in The Telegraph, 2013, January 23).

37 Blanchard, Olivier, "Is there a viable European social and economic model?", in MIT Department of Economics Working Paper, no. 06-21, 2006.

38 See Alber, Jens, "The European Social Model and the United States", in European Union Politics, vol. 7, no. 3, 2006, pp. 393-419 and Alber, Jens, "What the European and American welfare states have in common and where they differ: facts and fiction in comparisons of 
The European model reflects a model of organizing economic and social relations, which meets the special combination of economy, state and society, which is specific for the EU. ${ }^{39}$ In terms of economy, the European model aims to combine the dynamics of growth within a market economy with the dialogue involving social partners; regarding state, it should be noted that, besides the fact that they function as liberal democracies, EU member states are welfare states, which supplement market action through redistribution, in order to mitigate social inequalities; in relation to society, in addition to creating opportunities for individuals, the model promotes solidarity between individuals, thus strengthening social cohesion..$^{40}$

Over time, some important questions regarding the European model have been raised, some of which are still valid today:

- Will the model of the single market and of its four economic freedoms enhance in time or, on the contrary, will it disappear? We now have the EU with its 27 (soon 28) member states, supplemented by the EFTA ${ }^{41}$ countries, which leads to the remark that we are witnessing the institutionalization of all European countries, i.e. the gradual transfer of the European model in the entire European space, so that one comes to identify Europe with the EU and the European model with the model of the EU. All European countries are willing to be part of the EU or at least develop special relations with it.

- Could this economic model of the EU turn into a political one, which would eventually lead to the creation of the 'European Federation' the founding fathers were dreaming of? This goal can be achieved through extending the collective sovereignty to areas of high-politics, at least for a group of states, if not for all. The alternative would be the return to a classical - slightly changed - intergovernmental model, without strong common institutions and policies and without common laws. Nowadays, we can acknowledge that the European model has shown

the European Social Model and the United States", in Journal of European Social Policy, vol. 20, 2010, pp. 102-125.

39 See Alber, "The European Social Model and the United States”, p. 394 and Luzzaraga, Francisco Aldecoa; Llorente, Mercedes Guinea, Europa viitorului. Tratatul de la Lisabona, Iaşi: Ed. Polirom, 2011, p. 125.

40 Alber, "The European Social Model and the United States", p. 395.

41 The European Free Trade Association (EFTA) is an international organization promoting free trade and consisting of four European countries: Iceland, Lichtenstein, Norway, and Switzerland. EFTA operates in parallel, but cooperates closely with the EU. Through the free trade agreement called the European Economic Area (EEA), created by the Porto Agreement in May 1992, EFTA countries are allowed to participate in the common market and its sectoral policies. Through the EU accession of Finland, Sweden and Austria in 1995, the EEA has lost its practical importance and is now serving only Liechtenstein, Norway and Iceland (Switzerland, although an EFTA member, still remains outside the EEA, having special agreements - such as 'communicating vessels' agreements - with the EU, in this way avoiding isolation from the community environment it lives in). 
the credibility of the 'shared sovereignty' method through successive institutional reforms and extension of competences.

- Can the European economic and social model - based on the principles of social market economy - which places the citizen in the centre of the triad of economy-state-society - become a genuine model of society in Europe? This model of welfare and growth is situated between the socialist-communist model, which aims to overcome social inequalities through abolishing the free market, and the classical model of laissez-faire liberalism ${ }^{42}$, in which the market is absolutely free and no state intervention is welcomed. Nowadays, one can say that the EU adopted this economic policy model through implementing specific actions and policies which define what is called the 'European social model'. Currently, all EU member states - including the UK - have their own social policies and, at the same time, they participate in common programs and projects on different social-related issues. The European Constitution took a step forward in this regard by institutionalizing this European model seen as EU's own distinctive economic and social model. The Lisbon Treaty also maintained this direction. Even in the current crisis, debates are not about abandoning the European model, but rather preserving it as a true 'heritage'.

- Are the EU and its member states able to have their 'own voice' in international affairs and, more specific, what are their commitments with already wellestablished organizations, such as NATO or Warsaw Pact ${ }^{43}$, or with neutral states? Can the EU - as an international actor - impose itself beyond the member states and progressively substitute them on issues of foreign policy? After 40 years, the EU has developed a common foreign and security policy, autonomous and compatible with both the one of NATO and the one of neutral states. Moreover, in its quest for developing a common voice on global scale, the EU has created a real European External Action Service and a true European Foreign Minister.

All these questions and their corresponding answers point to the fact that the model of the EU aims to become the European model. Therefore, it is a continental model which promotes a balance between society, economy and politics, and in which the citizen should play the central role.

\section{The impact of the crisis on the European model: what flaws} in the design of the model did the crisis highlight?

The multiple crises of the late 2000s, but especially the Eurozone debt crisis, have exposed some of the imperfections of the European model regarding its economic dimension and, to be more precise, the ones related to the economic governance

42 This model is representative for North American states.

43 The Warsaw Pact was designed in 1955 as a communist alternative to NATO and as military complement to the COMECOM. It was also led by the USSR and was dissolved in 1991. 
and structure of its Economic and Monetary Union (EMU). It is true that EU integration experts (mostly economists) have warned about some of them for some time and called for more political action to try to correct them. In this context, it is not the case to consider the European model to be fully wrong and completely abandon it. On the contrary, this gives EU leaders and 'designers' the opportunity to reflect upon the mistakes and try to come up with solutions to perfect the model and make it more sustainable.

The most significant and thus fundamental flaw in the European model is believed to lie in the institutional design of the European Economic and Monetary Union $^{44}$. Ever since its creation, specialists have argued that the EMU doesn't fulfil all the requirements for an optimal currency area (OCA)..$^{45}$ Although the EU's internal trade amounts a considerable part of EU's trade ${ }^{46}$, labour mobility within the EMU seems to be limited ${ }^{47}$, making it impossible to balance economic shocks through labour migration. Although one might argue that the member states of the EMU have quite similar manufacturing structures ${ }^{48}$, they differ significantly in their basic economic structures. The main differences lie between the more tech-

44 See Dăianu, Daniel, "Euro zone crisis and EU governance: Tackling a flawed design and inadequate policy arrangements", in CASE Network Studies \& Analyses, no. 433, 2012.

45 According to Mundell's theory, presented in his paper "A Theory of Optimum Currency Areas" (The American Economic Review, vol. 51, no. 4, 1961, p. 657), an optimal currency area (OCA) is "a domain within which exchange rates are fixed" and in which factor mobility is indispensable and should be particularly high. Krugmann and Obstfeld define in their book International economics: theory and policy (Boston: Pearson, 2009, p. 581) OCAs as "groups of regions with economies closely linked by trade in goods and services and by factor mobility" and discuss the issue of Europe being an OCA, while examining whether the EMU has the four properties they believe define a genuine OCA: intra-regional trade, labour force mobility, similarity of economic structures, the degree of fiscal federalism (ibid., pp. 582-587).

46 According to Eurostat, intra-EU trade in goods accounts for around $60 \%$ of the total EU-27 trade. In 2011, the share of intra-EU exports was $64,3 \%$, with $3,7 \%$ less than in 2000 , and the share of the imports $61,4 \%$, with a slight decrease of 2,1\% since 2000 (http://epp.eurostat. ec.europa.eu/tgm/refreshTableAction.do?tab=table \&plugin=1\&pcode=tet $00037 \&$ langua ge $=$ en, accessed on 15.02.2013). This small drop in intra-EU trade since 2000 (after an incremental increase in the first 5-6 years, it started decreasing in 2007) can be attributed mostly to the recession which hit the EU member states, following the outbreak of the world financial crisis in 2007-2008 and the accompanying recession.

47 Although the EU and more specifically the EMU is based on the Single Market, which allows the free movement of goods, services, capitals and people, the residents of the member states are still quite reluctant to moving from one state to another. This appears to happen both due to the incompleteness of the Single Market (i.e. governments seem to continue to preserve some regulations regarding labour mobility) and other factors such as language and cultural differences or differences in social security systems.

48 Krugman and Obstfeld (p. 585) identify the intra-industry trade (i.e. the trade with similar products) within the EU as a sign of the similarity in manufacturing structures of its member states. 
nologically endowed, highly-skilled and capital abundant north and the less technologically equipped, poorer skilled and less capitalized south. Given EU's limited competences in the fiscal field and, therefore, its reduced budget, neither has the EU got enough funds to be able to rescue a member state in economic difficulties, nor does it have the (legally-based) ability to transfer resources from the wealthy economies to the 'less fortunate' ones, based on the principle of fiscal federalism.

Given the fact that the member states within the EMU have to uniformly apply the common monetary policy dictated by the European Central Bank (ECB), they no longer possess the ability to use monetary policy instruments to correct the imbalances within their national economies. In other worlds, national governments have less policy instruments to tackle domestic problems. As a result, asymmetric shocks are more likely to appear throughout the EMU, because member states are used to reacting differently to a specific issue and, therefore, the 'one size fits all' monetary policy might not produce the expected positive outcome in all states. The more heterogeneous the economies of the EMU are, the greater will the asymmetry of the macroeconomic shocks be. For 'smoothening' these shocks, Krugman and Obstfeld ${ }^{49}$ call for more flexibility on the labour markets - a domain which still remains of national competence - both regarding wages and mobility of the labour force.

Before adopting the Euro, member states are supposed to comply with the Maastricht convergence criteria ${ }^{50}$, but in order to make the Union work properly and avoid creating asymmetric shocks, it is highly important that the economies develop similarly, thus creating real convergence ${ }^{51}$ between them. Even when looking at the main indicator of real convergence for the 17 member states of the Eurozone, i.e. the GDP per capita, one can observe quite big differences among the states: in 2011, the GDP per capita within the Eurozone ranged from $9100 € /$ inhabitant in Estonia to $33300 € /$ inhabitant in the Netherlands or even $64900 €$ / inhabitant in Luxembourg. ${ }^{52}$ These figures are quite representative for the heterogeneity in the Eurozone and this gap even increases when comparing the Eurozone states with the other members of the EMU. This poor convergence in the EMU

49 Ibid., p. 588.

50 The criteria are listed in the art. 140, line 1 of the Treaty on the Functioning of the EU (2010, p. 108-109): price stability, public finance sustainability (both of the governmental budget deficit and of the public debt), exchange rates and long-term interest rates.

51 The real convergence of the member states' economies must be understood as convergence of the living standards throughout the Union. Some of the indicators for accessing the degree of this alignment are: the GDP per capita, the openness of the economy, the structure of the economy, the balance of payments and the labour costs (http://www.bnro.ro/Trecerea-laeuro-1251.aspx, accessed on 15.02.2013).

52 The numbers were taken from Eurostat: http://appsso.eurostat.ec.europa.eu/nui/ submitViewTableAction.do?dvsc $=6$, accessed on 15.03.2013. 
allowed tensions to appear between the states which have surpluses in their current account (i.e. Germany) and the ones running large deficits (i.e. Greece, Portugal). ${ }^{53}$

Regarding the issue of the insufficient institutional framework of the EMU, Dullien et al..$^{54}$ identify three important points in the EU primary law which might have contributed to the outbreak and deepening of the crisis. They first note that the EU Treaty includes an explicit 'no bail-out clause' in its provisions - art. 125 of the Treaty on the Functioning of the European Union ${ }^{55}$ - which prohibits a member state to take over the liabilities of another one. This clause didn't succeed in fulfilling its purpose of teaching national governments to run prudent fiscal policies, but it made the bailing-out of Greece and the other countries very difficult (in many parts also illegal). The Treaty also forbids the ECB to 'directly' finance government budgets - art. 123 TFEU. ${ }^{56}$ On this issue, there was a strong debate whether the ECB is allowed or not to purchase government bonds of the indebted states on the secondary market, Germany being categorically against this action..$^{57}$ Last but, not least, the Treaty left the supervision of the financial sectors to the member states and, since the coordination of national supervisors has been poor and there is no EU law regarding the liquidation of insolvent national or cross-border financial institutions, this situation allowed governments to bail-out banks at large scale and thus increase their debts. Dăianu ${ }^{58}$ also stresses out that the current EU arrangements for regulating and supervising the financial markets are fuzzy and inefficient; therefore, he highlights the need for "a common rulebook, more integrated supervision, and a common framework for crisis resolution". Dullien et al. ${ }^{59}$ sum up by saying that "the lack of a common resolution framework and a fiscal authority that would be able to pay in times of debt crisis explains some aspects of the euro crisis", such as the spread of the crisis to Italy and Spain.

To the above mentioned problems of the primary EU law framework, another one could be added: the lack of an 'exit clause' for the Eurozone.$^{60}$ Fahrholz and Wojcik $^{61}$ are in favour of introducing an 'exit clause' for the member states which

53 See Dăianu, p. 9.

54 Dullien, Sebastian; Fritz, Barbara; Mühlich, Laurissa, "Regional Monetary Cooperation: Lessons from the Euro Crisis for Developing Areas?", in World Economic Review, no. 2, 2013, p. 6.

55 EU 2010, p. 99.

56 EU 2010, p. 99.

57 See http://www.guardian.co.uk/business/nils-pratley-on-finance/2012/may/23/why-germany -doesnt-want-eurobonds, accessed on 15.02.2013.

58 Dăianu, p. 9.

59 Dullien, Fritz, Mühlich, p. 10.

60 According to the current primary law of the EU (i.e. the Treaty of Lisbon), there is no clause for member states' exiting the EMU, but only one regarding exist from the EU: art. 50 of the Treaty on the European Union (EU 2010, p. 43).

61 Fahrholz, Christian; Wójcik, Cezary, "The Eurozone Needs Exit Rules”, in CESifo Working Paper Series, no. 3845, 2012, pp. 1-25. 
have trouble with their domestic finances, because in this way it would help in finding a quicker solution to the Eurozone crisis and foster stability across the EMU. After briefly presenting some possibilities for formulating this clause, they ${ }^{62}$ argue that introducing such a rule would strengthen the Eurozone by reducing the possibility of moral hazard, fostering domestic macroeconomic discipline, increasing the political bargaining power of the Eurozone vis-a-vis the indebted states and reducing uncertainty regarding the procedure and costs of a Eurozone exist. Lastly, they suggest that, given its political and economic feasibility, this 'exit clause' should be given serious thought when reforming the institutional framework of the Eurozone.

Another important issue revealed by the crisis regarding the EMU is the inability of the member states to respect the rules within the Stability and Growth Pact (SGP). Breaking the SGP rules is not a novelty, since it is well known that the very country that advocated for introducing these rules of budgetary discipline (i.e. Germany) has many times been among the countries which failed to respect them. ${ }^{63}$ A reason for the repeated infringement of these rules could be attributed to the SGP's modest and selective sanctioning capabilities and the insufficient authority of the Commission to enact them accordingly. It was not until the emergence of the Eurozone crisis when European leaders understood the importance of respecting the SGP provisions. Both due to the bailing-out of banks affected by the global financial crisis or big public spending, states have come to accumulate deficits and public debts above the limits allowed by the SGP, thereby endangering the stability of the Euro currency. Given the poor coordination regarding fiscal discipline accomplished through the SGP, Dăianu ${ }^{64}$ argues in favour of an EMU fiscal authority, which would be able to provide the necessary funds, mechanism and instruments to make fiscal transfers across the EMU possible. This would call for greater coordination between national governments on budgetary issues, the creation of a substantial common Eurozone budget and the issuance of common bonds through the $\mathrm{ECB}^{65}$, all these based on the principles of fiscal federalism.

As Krugman and Obstfeld ${ }^{66}$ note, if the EMU will be a successful project, it will promote the European model throughout the entire Europe and beyond its borders;

62 Ibid., p. 16-20.

63 As also reflected in the statistics of the European Commission (see http://epp.eurostat. ec.europa.eu/tgm/table.do?tab=table \&init=1\&language $=$ en $\&$ pcode $=$ tec $00127 \&$ plugin $=1$, accessed on 15.02.2013), during 2002 - 2005, both Germany and France repeatedly violated the rules on government deficits within the SGP, but no sanctions have been imposed on them (http://www.guardian.co.uk/world/2003/nov/27/qanda.business, accessed on 15.02.2013), thus creating a case of double standards (other states were either punished for the rulebreaking or have made great efforts to abide them) and, at the same time, endangering the economic stability and growth of the EMU.

64 Dăianu, p. 9.

65 Ibid., p. 10.

66 Krugman, Obstfeld, p. 587. 
but if it fails, the goal of the political unification of Europe will suffer some further setbacks. Thus, a good long-term durable solution has to be found for the problems within the EMU in order to be able to think about going further with the political integration of the EU member states and/or expanding the European model to other states or regions.

\section{Thoughts on future developments of the European model}

The Eurozone crisis has put the EU at a new crossroad; it has to choose now between different scenarios: deepening by increasing the number of EU competences, the return of some competences to the national level, differentiated integration, some states exiting the EU or even more states joining the EU.

As a response to the multiple crises that hit the EU since 2007-2008 and in an attempt to fix some of the flaws of the European model, EU leaders agreed to important reforms in the economic governance of its EMU. As Kunstein and Wessels ${ }^{67}$ note, these reforms were undertaken both within the EU Treaty framework $^{68}$, thus using the 'Community method', and outside the Treaty framework ${ }^{69}$, using the 'intergovernmental method'. As one can observe when looking at the measures taken after the crisis, all efforts concentrated on making the EMU - more precisely the Eurozone - more efficient and increase its cohesion, thus only sometimes allowing the non-Euro states to join the initiatives of the Eurozone members (like in the case of the Euro-plus Pact or the TSCG). The roadmap towards a genuine EMU, agreed upon in the European Council in December $2012^{70}$, also focused

67 Kunstein, Tobias; Wessels, Wolfgang, "The New Governance of the Economic and Monetary Union: Adapted Institutions and Innovative Instruments", in Istituto Affari Internazionali Working Papers, vol. 13, no. 2, 2013, pp.1-13.

68 Kunstein and Wessels (p. 4) include in this category (1) the establishing of the European Systemic Risk Board and the European System of Financial Supervision in 2010 and the legislative proposal of creating the Single Supervisory Mechanism for an EU-wide supervision of banks; (2) the entry into force, in December 2011, of the 'Six-Pack' and of the 'Two-pack' in May 2013, a set of laws addressing fiscal and macroeconomic coordination and surveillance, and which partly use sanctions as a mode of coercion; they are meant to complement the SGP and the 'European Semester'; (3) the formalizing, in October 2011, of the Euro Summit, which gathers the Head of State or Government of the Eurozone states and meets at least two times a year.

69 The outside the Treaty reforms include, according to Kunstein and Wessels (p. 5): (1) the creation of the European Financial Stability Facility and of the European Stability Mechanism as temporary (in 2010), respective permanent (in 2012) internal crisis resolution mechanism; (2) the signing of the Euro-plus Pact, in March 2011, meant to improve the competitiveness of the signatory states (both Eurozone members and other EMU states); (3) the signing of the Treaty on Stability, Coordination and Governance (TSCG), in 2011, which aims at strengthening fiscal discipline at national level; the ratification process of this Treaty is still on-going.

70 See ECoun 2012 and van Rompuy, Herman, "Towards a genuine Economic and Monetary Union", Report presented in the European Council meeting in Brussels, 13-14 December 2012. 
on describing a step-by-step plan to achieve "deeper integration and reinforced solidarity" between the countries of the Euro area, as a sort of avantgarde of the EMU.

In today's context, Fischer's speech on the finality of European integration, held at the Humboldt University in Berlin in May 2000, returns to actuality. Fischer acknowledged the fact that the way to go further with the European model is through differentiated integration. $\mathrm{He}^{71}$ proposed that the states, which are determined to cooperate more closely than others, should be allowed to do so through enhanced cooperation, thus creating a more integrated core. This vanguardist group of states, formed of the Eurozone members ${ }^{72}$, is expected to develop into an economic and political union, having its own institutions and establishing a "new European framework treaty", putting the base for "the future federation". ${ }^{73}$ This core should be open to all member states and candidate countries, which would have to fulfil some requirements in order to join, but no member state could be forced to go further with the integration than it is able or willing to. For defining its idea of a closer integrated group of member states, Fischer used the term 'avantgarde', although he was referring to a 'Core Europe / Concentric circles' model of differentiated integration. ${ }^{74}$

Coincidentally or not, in his speech held in March 2012 at the Humboldt University in Berlin about the Euro crisis and the future of Europe, Piris ${ }^{75}$ also talked about the future of the EU in terms of differentiated integration, naming it 'two speed Europe', and proposing four scenarios. Among these scenarios, two referred to differentiated integration, having in centre the member states of the Eurozone: one in form of a de facto ${ }^{76}$ 'two speed Europe' and one of a de jure ${ }^{77}$

71 Fischer, pp. 7-8.

72 Although Fischer (p. 8) said that he had no answer to the question of which countries would form this core, his speech indicates that he had the Euro-states in mind.

73 Ibid.

74 According to Holzinger and Schimmelfennig's (p. 298) classification, the 'Avantgarde Europe' model applies only to EU members, but Fischer's model also talks about attracting candidate countries towards the more integrated centre, thus it would be more accurate to call it 'Core Europe / Concentric circles'.

75 Piris, Jean-Claude, "The Euro Crisis, Democratic Legitimacy and the Future Two-Speed Europe", Speech presented at the Humboldt University, Berlin, 2012, March 21.

76 Piris (pp. 8-9) notes that the closer political cooperation of the Euro-states should proceed within the current EU institutional and legal framework, taking advantage of the possibilities offered especially by art. 136 of the TFUE (EU 2010, p. 106) and for the rest, the group could use the intergovernmental method. Thus, he proposed some areas in which the group could decide to increase its cooperation within the Treaty's provisions (e.g. the coordination of national legislation on taxes and social policies; common measures regarding immigration policy; enhanced cooperation on judicial matters; permanent structured cooperation in the field of defence) and others in which it could close intergovernmental agreements (e.g. strengthening the ESM, the Euro-plus Pact; industrial cooperation).

77 The big difference to the other option is that the group would be legally established, through an international agreement. Piris (pp. 10-12) describes this arrangement as having a new legal basis, within which the states could establish new institutions (e.g. a smaller 
'two speed Europe'. Piris ${ }^{78}$ called for action towards a more integrated avantgarde Eurozone and stop complaining about a possible 'division of Europe', because he believes that deeper integration between the Euro-states is the only solution for the Eurozone and the EU as a whole. Although less convincing than Fischer, Piris noted that the more integrated core of the EU should be opened to accession by other EU member states ${ }^{79}$ under some conditions and that each EU member state should be allowed "to choose its own way and speed, in accordance with its needs and interests". 80

Based on the current developments within the EU and following the classification presented by Holzinger and Schimmelfennig, the authors see the EU moving towards a model of differentiated integration which has the Eurozone as a core and resembles to the 'Core Europe / Concentric circles' model of Holzinger and Schimmelfennig and the one of the 'European Onion' of De Neve. The authors believe that this type of integration within a small group of EU member states would extend to other policy areas and other member states of the EU or even to the candidate countries (the other 'layers') based on a functional and geographical / exogenous spill-over. Thus, in time, all the states in Europe would progressively be attracted towards the more integrated core of the EU (due to the benefits offered by the closer cooperation) and engage in more political cooperation, which could in the end lead to the creation of the European Federation.

But, it still remains arguable whether, on the long run, it is desirable for the EU to move towards the (pan-)European federation, or whether it ought to continue existing as an 'Unidentified Political Object's1 with its particular way of functioning and its community vision ${ }^{82}$ based on 'unity in diversity'. As President van

Commission; EU Council formations only for the Eurozone states, given that the Euro Summit already operates; a parliamentary assembly composed of representatives of the national parliaments concerned) and also broaden their area of cooperation (e.g. integrated system of macroeconomic surveillance and control; harmonizing tax and social legislation; increase cooperation on security and defence, but also regarding justice and home affairs, citizens' rights and mobility).

78 Ibid., pp. 13-14.

79 Here occurs a slight difference from Fischer's vision because Piris doesn't refer to candidate countries, thus describing with his de jure 'two speed Europe' (after the establishing of the new international agreement) an example of 'Avantgarde Europe', according to Holzinger and Schimmelfennig's (p. 298) classification.

80 Piris, p. 14.

81 Delors, Jacques, "Speech by Jacques Delors to the inaugural session of the Intergovernmental Conference, Luxembourg, 9 September 1985", p. 2.

82 This vision describes the EU as a group of associated nations sharing common interests or a common heritage, but each of these nations preserves its own specificity, while respecting the particularities of the others. For more on this subject, see Weiller, Joseph H.H., "Back to the Future: Europe as Community", in Collegium, no. 28, 2003, pp. 43-50. 
Rompuy ${ }^{83}$ wrote in his report on the roadmap towards a genuine EMU: " More Europe' is not an end in itself, but rather a means for serving the citizens of Europe and increasing their prosperity". Thus, one can conclude that the goal isn't for the EU to develop into a state-like federation, but to deliver welfare to the peoples of Europe, may it occur through more political integration of all member states or only of some states willing to go further. Therefore, the authors agree with Kunstein and Wessels ${ }^{84}$ and predict a near future of 'more Europe' in terms of deeper political integration, but 'less Europe' in terms of the number of states pushing for more integration.

\section{Bibliography}

Alber, Jens (2006), "The European Social Model and the United States", in European Union Politics, vol. 7, no. 3, pp. 393-419.

Alber, Jens (2010), "What the European and American welfare states have in common and where they differ: facts and fiction in comparisons of the European Social Model and the United States", in Journal of European Social Policy, vol. 20, pp. 102-125.

Bărbulescu, Iordan Gh. (2001), Uniunea Europeană: Extindere şi aprofundare, București: Editura Trei.

Bealey, Frank; Johnson, Allan G. (1999), The Blackwell dictionary of political science: A User's Guide to Its Terms, Oxford, Massachusetts: Blackwell Publishing Ltd.

Blanchard, Olivier (2006), "Is there a viable European social and economic model?", in MIT Department of Economics Working Paper, no. 06-21.

Cameron, David (2013, January 23), "David Cameron's EU speech in full" [online], in The Telegraph. Available online at http://www.telegraph.co.uk/news/worldnews/europe/ eu/9820230/David-Camerons-EU-speech-in-full.html accessed on 15.02.2013.

Dăianu, Daniel (2012), "Euro zone crisis and EU governance: Tackling a flawed design and inadequate policy arrangements", in CASE Network Studies \& Analyses, no. 433.

Delors, Jacques (1985, September 9), "Speech by Jacques Delors to the inaugural session of the Intergovernmental Conference, Luxembourg, 9 September 1985". Available online at http:// www.cvce.eu/content/publication/2001/10/19/423d6913-b4e2-4395-9157-fe70b3ca8521/ publishable_en.pdf accessed on 15.02.2013.

Dullien, Sebastian; Fritz, Barbara; Mühlich, Laurissa (2013), "Regional Monetary Cooperation: Lessons from the Euro Crisis for Developing Areas?", in World Economic Review, no. 2, pp.1-23.

Fahrholz, Christian; Wójcik, Cezary (2012), "The Eurozone Needs Exit Rules”, in CESifo Working Paper Series, no. 3845, pp. 1-25.

Fischer, Joschka (2000, May 12), "From Confederacy to Federation - Thoughts on the finality of European integration", Speech presented at the Humboldt University, Berlin. Available online at http://www.cvce.eu/obj/speech_by_joschka_fischer_on_the_ultimate_objective_of_ european integration berlin 12 may 2000 -en-4cd02fa7-d9 d0-4cd2-91c9-2746a3297773. $\mathrm{html}$ accessed on $15 . \overline{2} .2013$.

83 van Rompuy, p. 3.

84 Kunstein, Wessels, p. 11. 
Haas, Ernst B. (1958), The Uniting of Europe. Political, social and economic forces 1950 1957, Stanford: Stanford University Press.

Holzinger, Katharina; Schimmelfennig, Frank (2012), "Differentiated Integration in the European Union: Many Concepts, Sparse Theory, Few Data”, in Journal of European Public Policy, vol. 19, no. 2, pp. 292-305.

Krugman, Paul R.; Obstfeld, Maurice (2009), International economics: theory and policy. 8th Edition. Boston: Pearson.

Kunstein, Tobias; Wessels, Wolfgang (2013), "The New Governance of the Economic and Monetary Union: Adapted Institutions and Innovative Instruments", in Istituto Affari Internazionali Working Papers, vol. 13, no. 2, pp. 1-13.

Leuffen, Dirk; Rittberger, Berthold; Schimmelfennig, Frank (2012), Differentiated Integration: Explaining Variation in the European Union, Basingstoke: Palgrave Macmillan.

Lindberg, Leon N. (1963), The Political Dynamics of European Economic Integration, Stanford: Stanford University Press.

Luzzaraga, Francisco Aldecoa; Llorente, Mercedes Guinea (2011), Europa viitorului. Tratatul de la Lisabona, Iaşi: Ed. Polirom.

Mundell, Robert A. (1961), "A Theory of Optimum Currency Areas", in The American Economic Review, vol. 51, no. 4, pp. 657-665.

de Neve, Jan-Emmanuel (2007), "The European Onion? How Differentiated Integration is Reshaping the EU", in European Integration, vol. 29, no. 4, pp. 503-521.

Niemann, Arne; Schmitter, Philippe C. (2009), "Neofunctionalism", in Wiener, Antje; Diez, Thomas (eds.), European Integration Theory, New York: Oxford University Press.

Piris, Jean-Claude (2012, March 21), "The Euro Crisis, Democratic Legitimacy and the Future Two-Speed Europe", Speech presented at the Humboldt University, Berlin. Available online at http://www.whi-berlin.eu/tl_files/FCE/Rede-Piris.pdf accessed on 15.02.2013.

van Rompuy, Herman (2012, December 5), "Towards a genuine Economic and Monetary Union”, Report presented in the European Council meeting in Brussels, 13-14 December 2012. Available online at http://www.consilium.europa.eu/uedocs/cms_data/docs/pressdata/ $\mathrm{RO} / \mathrm{ec} / 134355 . \mathrm{pdf}$ accessed on 15.02.2013.

Sawicki, Iwona (2002), "Growing Regionalism in a Shrinking World", in European Policy Centre Working Papers.

Stubb, Alexaner C.-G. (1996), “A Categorization of Differentiated Integration”, in Journal of Common Market Studies, vol. 34, no. 2, pp. 283-295.

Stubb, Alexander C-G. (1997), "The 1996 Intergovernmental Conference and the management of flexible integration", in Journal of European Public Policy, vol. 4, no. 1, pp. 37-55.

Stubb, Alexander C-G. (2002), Negotiating Flexibility in the European Union, Basingstoke: Palgrave.

Weiler, Joseph H.H. (2003), "Back to the Future: Europe as Community”, in Collegium, no. 28, pp. $43-50$.

European Commission (EComm) (2012a), "Public Opinion in the European Union: First Results", in Standard Eurobarometer, no. 78. Available online at http://ec.europa.eu/public_opinion/archives/eb/eb78/eb78_first_en.pdf accessed on 15.02.2013.

European Commission (EComm) (2012b), "Public Opinion in the European Union: Annex", in Standard Eurobarometer, no. 78. Available online at http://ec.europa.eu/public_opinion/ archives/eb/eb78/eb78_anx_en.pdf accessed on 15.02.2013.

European Council (ECoun) (2012), Brussels European Council 13/14 December 2012. Presidency Conclusions, Brussels. Available on-line at http://www.consilium.europa.eu/uedocs/cms_data/docs/pressdata/en/ec/134353.pdf accessed on 15.02.2013. 
European Union (EU) (2010), Consolidated Treaties. Charter of Fundamental Rights, Publications Office of the European Union, Luxembourg. Available on-line at http://europa. eu/pol/pdf/qc3209190enc_002.pdf accessed on 15.02.2013.

http://www.guardian.co.uk/business/nils-pratley-on-finance/2012/may/23/why-germanydoesnt-want-eurobonds accessed on 15.02.2013.

http://epp.eurostat.ec.europa.eu/tgm/table.do?tab=table \&init=1\&language=en \&pcode=tec0012 $7 \&$ plugin $=1$ accessed on 15.02.2013. 